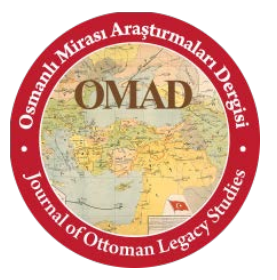

Osmanlı Mirası Araştırmaları Dergisi (OMAD) , Yıl 1, Sayı 1, Kasım 2014, ss. 74-77.

Journal of Ottoman Legacy Studies (JOLS), Volume 1, Issue 1, November 2014, pp. 74-77.

ISSN 2148-5704

\title{
Hale Yılmaz, Becoming Turkish: Nationalist Reforms and Cultural Negotiations in Early Republican Turkey, 1923-1945, Syracuse University Press, Syracuse, New York 2013.
}

\section{Evren J. TURAN*}

Becoming Turkish is a social history of the nationalist reforms implemented in the early Turkish Republic from the birth of the state in 1923 through the establishment of a two party system of government in 1945. The author presents the personal experiences of a wide array of Turkish citizens and their varied perceptions, evolving ideas, and utilitarian coping mechanisms formed in response to Kemalist reforms. In addition, she shows the agency of citizenship through primary sources such as petitions and letters that seemingly influenced government decisions. Not focusing on the resistance or suppression of the Kemalist reforms, Yilmaz employs oral histories, letters, and archival data to reveal diverse reactions that did not simply fall into two polarizing choices of brutal resistance or absolute acceptance. The uneven and incomplete way in which new Turkish citizens experienced and perceived the four areas of reform detailed by Y1lmaz was mirrored by legislative and governmental inconsistencies in the implementation and interpretation of these laws. The four reforms used to explore "state-society relations" in the early Turkish Republic include: "men's clothing, women's clothing, language, and national celebrations." The author exemplifies how Turks from various economic, cultural, and demographic categories converged with the state in "meeting grounds" and how "dialogue between the state and society" shows a true reflection of how Turks lived and experienced these reforms.

Becoming Turkish is a social history that explores how new Turks, "experienced, promoted, contested, and negotiated" the Kemalist reforms in major cities and minor provinces. The author focuses on commonly overlooked segments of Turkish society such as women, children, and the rural poor. She still covers the influence of both government officials and men in private and public life. Y1lmaz expands on prior social histories by including, "new written, oral and visual evidence..." in order to provide a fuller understanding of the chosen reforms, as well as to add a regional context to the "Turkish modernist experience" (11). The author's thesis connects "how individuals negotiated the meanings of the reforms with the state authorities," and developed a collective historical memory through laws, changing societal norms, propaganda, language, and national holidays (9). In addition, this work details how the Republican Public Party (RPP)government utilized "mediating institutions and individuals such as governors, courts, judges, the People's Houses, the Directorate of Religious Affairs and the imams, and schools” to regulate and instill their nationalist policies on the local level (9). Unevenness and inconsistency characterized Turkish citizens' receptions to and perceptions of Kemalist reforms; generational gaps, "language, class, ethnicity, gender, regional and local specificities, and individual choice” were all factors in these outcomes (10).

The first chapter, which covers titled reforms on men's clothing in the early republic, begins with the Ottoman background and points to the significance of European influences on

\footnotetext{
* University of Texas Pan American, Edinburg, Texas/USA, e-mail: ejturan@gmail.com
} 
men's costume prior to the republic. A link to late Ottoman history emphasizes that Western examples of fashion, ideology, and script were practiced prior to the new republic; however this exposure had class and demographic boundaries, primarily influencing urban middle- and upper-class citizens. In the late Ottoman period, many urban male professionals wore Western dress with a fez, thus this hat was seen as a link to Ottoman backwardness and was the primary focus of the Hat Law of 1925 (22). The Hat Law prohibited all "ethnic, traditional, or religious forms of headgear" and required a change in the daily habits of many men with the requirement of Western hats (fedoras or caps) (22). The goal was to remove all types of non-Western headgear such as the fez and create a new homogeneous Turkish citizen. To numerous men the law was seen as an intrusion into routine, other men could not comply due to economic difficulties and the limited supply of hats in rural areas. As a result, many men created their own hats, avoided public spaces in the short-term, or borrowed hats when entering provincial capitals with overseeing officials. Reforms did not touch all areas of the country equally. Westernization of clothing was slower to take hold in rural and impoverished areas where religious and tribal affiliations were stronger. In the absence of government officials to regulate the observance of reform laws, preference and utility often took precedence over reform compliance. As a result of the diverse circumstances of individual experiences, there were differing ideas and degrees of acceptance for the Hat Law and other clothing laws contained in the Kemalist reforms. Excerpts of letters show private individuals not in state employment both opposing and supporting reforms for economic and nationalistic reasons (59).

The second chapter covers how Turkish women were affected by clothing laws and their diverse reactions based on economic, demographic, and degree of patriarchal control. Y1lmaz fills a gap in the histiography that largely ignores women in this period by depicting how important Turkish women were perceived as being by the new Turkish republic. Women gained agency and it is important to show that they made choices, although they were often limited. The çarşaf, a "single piece of cloth that loosely covered a women's entire body" and peçe, a veil that covered the face, like the fez for men, came to be seen by the Kemalist government as symbols of a failed Ottoman past; Western garb was to replace them to create a homogeneous female Turkish citizen. Again, a link to Ottoman history is provided to detail how Turkish women's clothing developed and adapted in the twilight of the empire. Western fashion and influence was limited to urban areas where trade was prevalent and people from other nations were known to frequent. Unlike men's clothing, women's clothing did not have a national law that was strictly enforced. It seems that men's reactions to uncovering their women and the possibility of revolt kept the state from pushing too hard, too fast. Disagreements within the Republican Public Party on how to deal with women who refused to change their clothing caused an uneven application of the law (96). Like men, women's resistance was not limited to violent outbursts or obvious rebellion, instead the author uses a term "weapons of the weak," coined by James C. Scott, to describe everyday measures of disagreement. Tactics such as staying at home lasted much longer for women than men or adopting umbrellas to shield themselves from view, were some methods of resistance employed by women.

The third chapter analyzes how the alphabet reform of 1928 was implemented, perceived, and adapted by the Turkish citizenry. The author argues that alphabet change should be understood not only "in the context of the early Republican state's nationalizing, secularizing language reforms" but also within the "context of its modernist, developmentalist goals, for which a literate society was a prerequisite" (140). The new Turkish alphabet was seen as a method to purge Arabic and Iranian elements from the Turkish language and encourage growth and education. The uneven nature of the adoption of the new alphabet was seen even in government offices where officers used Ottoman for official correspondence and people continued using the Ottoman in public and private life. The population that was older and had used Ottoman for an extended period of their lives were slower to adapt, or refused to adopt the new script at all. In addition, the illiterate, a vast majority of the population, often had unequal 
access to schools and resources, thus many in the population did not have access to new books, schools, and instructors (150). Regardless of the uneven distribution of resources from the state, literacy and the new alphabet was more positively received than the clothing reforms.

The fourth chapter, titled "Celebrating National Holidays," describes holidays on the national and local level as well as their importance in creating a community with a shared "historical memory and collective identity" (180). National holidays were the most popular and inclusive of the Kemalist reforms, however they are often overlooked by prior scholarship despite their impact on many Turkish citizens' ideology and perception of their country. Ottoman ceremonies and holidays commemorated important days for the Sultan and the empire. In the new Turkish Republic, Mustafa Kemal Atatürk was substituted for the Sultan as the charismatic and noble head of state to be celebrated for his victories in the War of Liberation (179). New national holidays were tied to important military victories and days for the republic. The author utilizes elements of post-modern theory in this chapter in her mention of 'invented traditions' taken from Eric Hobsbawm, or in Benedict Anderson's term 'collective amnesia' (179). These important nationalist theorists and their ideas have influenced a wide array of authors; the application of their thought to Turkish nationalism, and to national holidays in particular, allows for a more complete understanding of their significant role in creating a shared national consciousness. The most important national holiday is Republic Day, the day republic was proclaimed in October 29th (182). Many holidays had duel significance: for example, the April 23 is both "National Sovereignty and Children's Day" festivals held on this day throughout the country advocated children's rights and welfare as well as nationalist speeches, songs, balls, and parades (184). National holidays were subject to the economics of the city or town where they occurred. Despite economic disparity, many rural towns still conducted smaller less elaborate festivities, creating nationalist sentiment through written prose, music, and communal gathering.

Y1lmaz's work contributes greatly to the historiography of Turkish nationalism. The social aspect of her work incorporates groups that have been historically ignored or relegated to the periphery. In analyzing the effects of Kemalist reforms on women, children, elderly, rural townsfolk, and those in poverty, Y1lmaz has furthered the understanding of non-elitist groups' role in creating a new Turkish nation. The use of extensive primary sources is seen throughout the work; oral histories, newspapers, letters, and governmental archives provide insight into the individuals who shaped policy in both private and public spheres of life. Citizens shaped the views of the RPP government though petitions and letters; this correspondence could echo public opinion as a whole and was not ignored by policy makers. By illustrating examples where individuals not working for the state both advocated for and against new reforms, the myth of a monolithic reaction can be dismissed easily. Governmental sources such as the Archive of the Ministry of the Interior have seldom been used in general, and never for a social historical approach (19). Archival data's importance in understanding various aspects of this study can not be overlooked. Insight into disagreement within different agencies, and a lack of a cohesive interpretation of the reforms, is vividly depicted through state documents.

A stranger to the Turkish nationalist movement would be quite comfortable with the author's preliminary explanations of historical precursors and events that led up to the period covered in this work. Maintaining objectivity is of the utmost importance to Yilmaz, she often shows all sides of a situation in order to paint a complete picture of complex state-individual relations. The author notes that she does not cover all Kemalist reforms and certainly the four chosen do reflect her interests and prior scholarship; this study is not a survey and thus could not cover all areas of reform in detail. The secondary research conducted by Yilmaz is extensive and provides insight into other contributions to the histiography and their connections to her work. 
An invaluable source to understanding individual life during the Kemalist reforms, Becoming Turkish is both highly readable and enjoyable. The years of development and research that were required to write this work provide amore complete and interesting perspective into nation building. Great man histories and works from an exclusively governmental perspective have their places in Turkish nationalist scholarship. However, authors such as Hale Yilmaz continue to develop new perspectives and provide agency to historically overlooked individuals and groups that were instrumental in the development of the new Turkish state. 